\title{
Lung Giant Cell Carcinoma
}

National Cancer Institute

\section{Source}

National Cancer Institute. Lung Giant Cell Carcinoma. NCI Thesaurus. Code C4452.

A morphologic variant of lung sarcomatoid carcinoma characterized by the presence of mononuclear and multinucleated pleomorphic neoplastic giant cells that lack cohesion. 